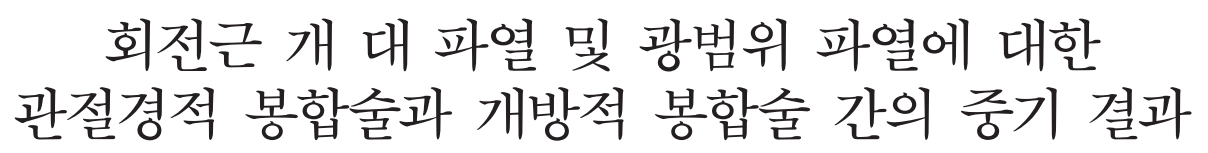

전북대학교 의학전문대학원 정형외과학교실

왕성일 · 박종혁

\title{
A Mid-Term Reults of Arthroscopic Versus Open Repair for Large and Massive Rotator Cuff Tears
}

\author{
Seong-Il Wang, M.D., Jong-Hyuk Park, M.D. \\ Department of Orthopedic Surgery, Chonbuk National University Medical School, Jeonju, Korea
}

\begin{abstract}
Purpose: To compare the mid-term clinical results of arthroscopic and open repair for large to massive rotator cuff tear.

Materials and Methods: We retrospectively reviewed 48 patients who underwent either arthroscopic or open repair for large to massive rotator cuff tear. 28 patients underwent arthroscopic repair and 20 patients had open repair. The clinical outcome for the 2 groups was evaluated using range of motion, Visual Analogue Scale (VAS) for pain and function, American Shoulder and Elbow Society (ASES) score and Korean Shoulder Scoring System (KSS) score.

Results: The range of motion, VAS for pain and function and ASES score was improved significantly in both groups at the final follow-up visit compared with preoperative values. However, there were no significant differences between the two groups statistically $(p>0.05)$. There were no significant differences between the two groups statistically at the final follow-up KSS score $(p>0.05)$ either.

Conclusion: We could obtain improved mid-term clinical outcomes in both arthroscopic repair and open repair without any statistically significant differences between the two groups.
\end{abstract}

Key Words: Rotator cuff, Large tear, Massive tear, Arthroscopic repair, Open repair

\section{서 론}

회전근 개 파열은 성인에서 견관절 통증이나 기능장
애를 일으키는 흔한 병인 중의 하나로서 ${ }^{1)}$ 통증 감소 및 관절운동 범위나 근력의 회복을 위해서는 수술적 봉합 을 통한 해부학적 복원이 필요하다. 그러나, 대 파열이

\footnotetext{
※통신저자: 박 종 혁

전북 전주시 덕진구 금암동 $634-18$

전북대학교병원 정형외과학교실
}

Tel: 063) 250-1760, Fax:063) 271-6538, E-mail: nuga4u@chonbuk.ac.kr

접수일: 2011년 10월 31일, 1차 심사완료일: 2011년 11월 7일, 2차 심사완료일: 2011년 12월 7일, 게재 확정일: 2011년 12월 16일

* This paper was (partially) supported by the CBNU funds for overseas research, 일련번호-2008. 
나 광범위 파열은 만성적인 파열이 흔하며 회전근 개의 변성으로 치유능력이 저하되어 있어 기술적으로 만족스 러운 봉합이 어렵다. ${ }^{2)}$ 또한 소 파열이나 중 파열에 비 해 재파열이 흔한 것으로 보고되고 있다. ${ }^{3)}$ 이에 $\mathrm{Pau}^{-}$ los와 Kody는 만성적인 회전근 개 대 파열이나 광범위 파열이 있을 경우 개방적 봉합술을 제안하였다. ${ }^{4)}$ 그러 나, 개방적 봉합술은 술 후 통증의 지속 시간이 길고 견봉내 삼각근의 재부착에 따른 조기 재활에 제한이 있 다. 한편, 회전근 개 봉합에 관절경적 봉합술이 소개되 며 초기 우수한 임상 결과들이 보고되었으나 대 파열이 나 광범위 파열이 배제된 주로 소 파열이나 중 파열에 서의 비교라는 제한점이 있었다. ${ }^{5-7)}$ 그리고 근래 대 파 열이나 광범위 파열의 관절경적 봉합 후 만족스러운 결 과가 보고되고 있으남.9) 개방적 봉합술과의 중기 결과 보고는 드물다. 이에 저자들은 회전근 개 대 파열 및 광범위 파열에서 관절경적 봉합술과 개방적 봉합술을 시행한 군간의 중기 임상적 결과를 비교 분석하였다.

\section{대상 및 방법}

\section{1. 연구 대상}

2004년 3월부터 2008년 4월까지 회전근 개 대 파열 및 광범위 파열로 봉합술을 시행한 80예 중 1) 관절와상완골간 심한 관절염이나 무혈성 괴사가 동반된 2예, 2) 이전 견관절 수술 기왕력이 있는 4예, 3) 견봉 쇄골 관절염이 동반되어 관절경 하 혹은 개방적 원위 쇄골 절제술을 시행한 3예, 4) 견갑 관절 주위 골절이 동반 된 2예, 5) 소 절개를 통한 봉합술 8예를 제외한 61예 의 환자에서 최소 3 년 이상의 추시가 가능하였던 48 예 (대 파열 29예, 광범위 파열 19예)를 후향적으로 분석 하였다. 회전근 개 파열의 크기는 수술 시에 탐색침을 이용하여 파열된 부분 중 가장 긴 부분을 측정하여 DeOrio와 Cofield ${ }^{10)}$ 의 분류에 따라 $3 \mathrm{~cm}$ 이상 $5 \mathrm{~cm}$ 미만을 대 파열로 분류하였으며 광범위 파열은 전층 파
열된 회전근 개 건이 2 개 이상이거나, 파열 단면의 가 장 넓은 길이가 $5 \mathrm{~cm}$ 이상인 경우로 정의하였다. ${ }^{11)}$ 환 자군을 두 그룹으로 나누어 $\mathrm{A}$ 군은 관절경적 봉합술을 시행한 28 예였고, $\mathrm{B}$ 군은 개방적 봉합술을 시행한 20 예 였다.

수술 방법은 2004년 3월부터 2005년 6월까지 모든 대파열과 광범위 파열에 대해 개방적 봉합술이 시행되 었고 2005년 7월부터 2006년 1월까지 관절경적 술기의 숙달기간 동안 파열의 범위와 관절경적 봉합 가능 여부 를 술자가 판단하여 수술 방법을 선정하였다. 한편, 관 절경적 술기의 숙달기간 중 소 절개에 의한 봉합술이 8 예 시행되었으나 본 연구 대상에서 제외하였고 개방적 봉합술 20 예 중에는 관절경하 봉합 나사를 삽입하였으 나 골의 상태가 불량하여 수술 시야상 봉합 나사못의 빠짐이 관찰되어 관절경적 봉합술에서 개방적 봉합술로 전환한 경우가 2 예 있었다.

평균 추시기간은 관절경적 봉합술군은 38.2 (범위: $36 \sim 41$ )개월, 개방적 봉합술군은 40.7 (범위: 36 50) 개월 이었다. 성별, 연령, 외상력, 추시 기간, 파열 크 기, 골밀도 및 견관절에 중.고도의 긴장이 주어지는 직 업 유무 등에 대하여 두 군 간의 통계학적으로 유의한 차이는 없었다 $(p>0.05)$ (Table 1$)$.

\section{2. 수술 수기}

측와위로 눕히고 견관절 내 관절경술을 시행하여 회 전근 개 파열 때 동반할 수 있는 관절내의 병변이 있는 지 확인하였으며 견갑하건 파열 여부를 평가하여 상위 $1 / 2$ 의 파열인 경우에는 관절경하에서 봉합을 시행하였 다. ${ }^{12.13)}$ 관절경을 견봉 하 공간에 삽입한 후 모든 예에 서 견봉 성형술을 시행하였으며 회전근 개 파열의 범위 와 봉합 가능성을 평가한 후 봉합 나사를 이용하여 대 결절부에 봉합하였다.

개방적 봉합술은 Langer's line 을 따라 약 8 10 $\mathrm{cm}$ 정도의 피부 절개를 한 후, 삼각근을 견봉으로부터

Table1. Demographic Data of Patients

\begin{tabular}{lccc}
\hline \hline & Group A & Group B & $p^{*}$-value \\
\hline Case (M/F) & $28(12 / 16)$ & $20(7 / 13)$ & NS \\
Age (range) & $66.9(51-76)$ & $68.2(56-75)$ & $\mathrm{NS}$ \\
History of Trauma & $12(42.9 \%)$ & $8(40 \%)$ & $\mathrm{NS}$ \\
Elapsed time to op (ms) & $11.9(1-48)$ & $13.1(1-60)$ & $\mathrm{NS}$ \\
Follow up (range) & $38.2(36-41)$ & $40.7(36-50)$ & $\mathrm{NS}$ \\
Tear size (Large/ Massive) & $19 / 9$ & $11 / 9$ & $\mathrm{NS}$ \\
BMD (range) & $-1.8(1.0 \sim-3.6)$ & $-2.2(-0.4 \sim-3.8)$ & $\mathrm{NS}$ \\
Medium to high shoulder strain at work & $9(32.1 \%)$ & $6(30 \%)$ & $\mathrm{NS}$ \\
\hline
\end{tabular}

Group A, Arthroscopic repair, Group B, Open repair, $p^{*}: \boldsymbol{x}^{2}$ test, NS: No significant. 
분리하여 견봉 및 회전근 개를 노출하였으며, 견봉 성 형술 후 회전근 개와 주변과의 유착을 충분히 박리하였 다. 모든 예에서 대 결절 부위를 소파한 후, 대부분의 경우에서는 골 결손을 줄이기 위해 봉합침 (needle) 을 이용한 최소 침습적인 방법으로 \#2 Ethibond 를 이용 하여 건과 골의 단속봉합을 시행하였으며, 일부에선 봉 합 나사 (suture anchor)를 이용하여 대결절부에 봉합 하였다.

재활은 두 군 모두 외전 보조기를 착용하였으며 파열 의 크기 및 수술 방법에 따라 3 6주간 고정하였다. 수 동적 관절 범위 운동은 파열의 크기나 수술 시 회전근 개의 조직 상태에 따라 3 6주 사이에 시작하였다. 수 동적 관절운동 범위가 회복됨에 따라 능동적 관절 운동 은 6주부터 시작하였으며 일상적인 작업이나 머리 위로 팔을 드는 활동은 술 후 3 개월에서 6 개월 사이에 근력 이 회복되는 것을 확인 후 허용하였다.

\section{3. 연구 방법}

수술 시야상 평가된 파열의 형태를 관절경적 봉합술 군과 개방적 봉합술군 간에 알아보았으며 각각의 군에 서 회전근 개 파열의 봉합을 위해 시행된 세부적인 봉 합 방법이나 추가적 처치에 대해 수술기록지를 바탕으 로 후향적으로 조사하였다.

임상적 평가는 관절운동 범위의 경우, 수술 전 과 술 후 3 개월, 6 개월 및 최종 추시에서의 전방 굴곡, 외전 및 외회전 범위를 평가하여 두 군간에 비교하였다. 또 한, 수술 전 과 술 후 3 개월, 6개월 및 최종 추시에서 의 통증 및 기능에 대한 Visual Analogue Scale $(\mathrm{VAS})$ 점수를 평가하였으며, 견관절 기능 평가는 미국 견주관절 학회 (American Shoulder and Elbow Society: ASES)의 기능 평가법 ${ }^{14)}$ 을 이용하여 평가하 였다. 한편, 최종 추시에서의 Korean Shoulder Scoring System (KSS) ${ }^{15)}$ 점수를 평가하여 두 군간에 비교하였으며 술 후 합병증에 대해서 알아보았다.

통계 분석은 SPSS version 17.0 (SPSS Inc., Chicago, IL, USA) 프로그램을 이용하였다. 비모수 검정으로 Mann- Whitney 검정을 사용하여 $\mathrm{A}$ 군과 $\mathrm{B}$ 군을 각각 비교하였다. 수술 전과 수술 후의 결과에 대 한 비교 분석은 nonparametric 변수에 대한 Wilcoxson rank test 를 이용하였다.

\section{결 과}

관절경적 봉합술을 시행한 $\mathrm{A}$ 군과 개방적 봉합술을 시 행한 $\mathrm{B}$ 군 모두 극상근 파열이 가장 많았으며 $\mathrm{B}$ 군에선 극상근과 극하근 및 견갑하근까지 파열된 광범위 파열
이 2예였다 (Table 2).

$\mathrm{A}$ 군에서는 모든 예에서 관절경하 견봉 성형술을 시행 한 후, 회전근 개 파열에 대해서 Super Revo ${ }^{\circledR}$ 를 이용 한 봉합이 11예, Bio-Corkscrew ${ }^{\circledR}$ 과 Bio-PushLock ${ }^{\circledR}$ 을 이용한 봉합이 17 예였고, 이열 봉합이 20예, 일열 봉합이 8예였다. 이중, 광범위 파열이 있었던 3 예에서 해부학적 봉합이 불가능하여 부분 봉합술을 시행하였 다. $\mathrm{B}$ 군에서는 17 예에서 개방적 견봉 성형술, 3 예에서 관절경적 견봉 성형술을 시행한 후 회전근 개 파열에 대해서 \#2 Ethibond 만을 이용한 봉합이 12예 였으며 \#2 Ethibond 와 Super-Revo ${ }^{\circledR}$ 을 이용한 봉합이 6예 였고 Super-Revo 만을 이용한 봉합이 2예였다. 이중, 극상근과 극하근 및 견갑하근까지 파열되었던 2 예를 포함한 광범위 파열3예에서 부분 봉합술이 시행되었다. 상완 이두 장두건에 대한 치료는 $\mathrm{A}$ 군에서는 건 절제 2 예, 건 고정 2 예, 건 변연절제술 2 예였고, $\mathrm{B}$ 군에서는 건 절제 3 예, 건 고정 3 예였다.

임상적 결과에서 관절운동 범위는 두 군 모두 수술 전에 비해 의미있는 향상을 보였으며 전방 굴곡 및 외 전 운동에선 술 후 3 개월에 $\mathrm{B}$ 군보다 $\mathrm{A}$ 군에서 통계학적 으로 유의한 향상을 보였으나 $(p<0.05)$ 술 후 6 개월부 터는 두 군간에 유의한 차이는 없었으며 최종 추시에 서 두 군간에 통계학적으로 유의한 차이는 없었다. 한 편, 외회전 운동은 두 군 모두 술 후 6개월부터 수술 전에 비해 의미있는 향상을 보였으며 최종 추시까지 두 군간에 유의한 차이는 없었다 (Fig. 1A, Table 3).

통증에 대한 $\mathrm{VAS}$ 점수는 두 군 모두 수술 전에 비해 의미있는 통증 감소를 보였으며 술 후 3개월에 B군보다 $\mathrm{A}$ 군에서 통계학적으로 유의한 통증 감소를 보였으나 $(p<0.01)$ 술 후 6 개월부터는 두 군간에 유의한 차이는 없었으며 최종 추시에서 두 군간에 통계학적으로 유의한 차이는 없었다 (Fig. 1B). 기능에 대한 $\mathrm{VAS}$ 점수 및 견관절 기능 평가인 $\mathrm{ASES}$ 점수는 두 군 모두 수술 전 에 비해 의미있는 기능 향상을 보였으며 술 후 3 개월과 6 개월에 $\mathrm{B}$ 군보다 $\mathrm{A}$ 군에서 통계학적으로 유의한 기능 향상을 보였으나 $(p<0.05)$ 최종 추시에서 두 군간에 통 계학적으로 유의한 차이는 없었다 (Fig. 1, Table 4).

Table 2. Type of Tears

\begin{tabular}{lcc}
\hline \hline & Group A $(\mathrm{n}=28)$ & Group B $(\mathrm{n}=20)$ \\
\hline SST & 19 & 11 \\
SST + IST & 7 & 5 \\
SST + SCT & 2 & 2 \\
SST+IST+SCT & 0 & 2 \\
Biceps tear or subluxation & 4 & 7 \\
\hline
\end{tabular}

SST: supraspinatus tendon, IST: infraspinatus tendon, SCT: subscapularis tendon. 

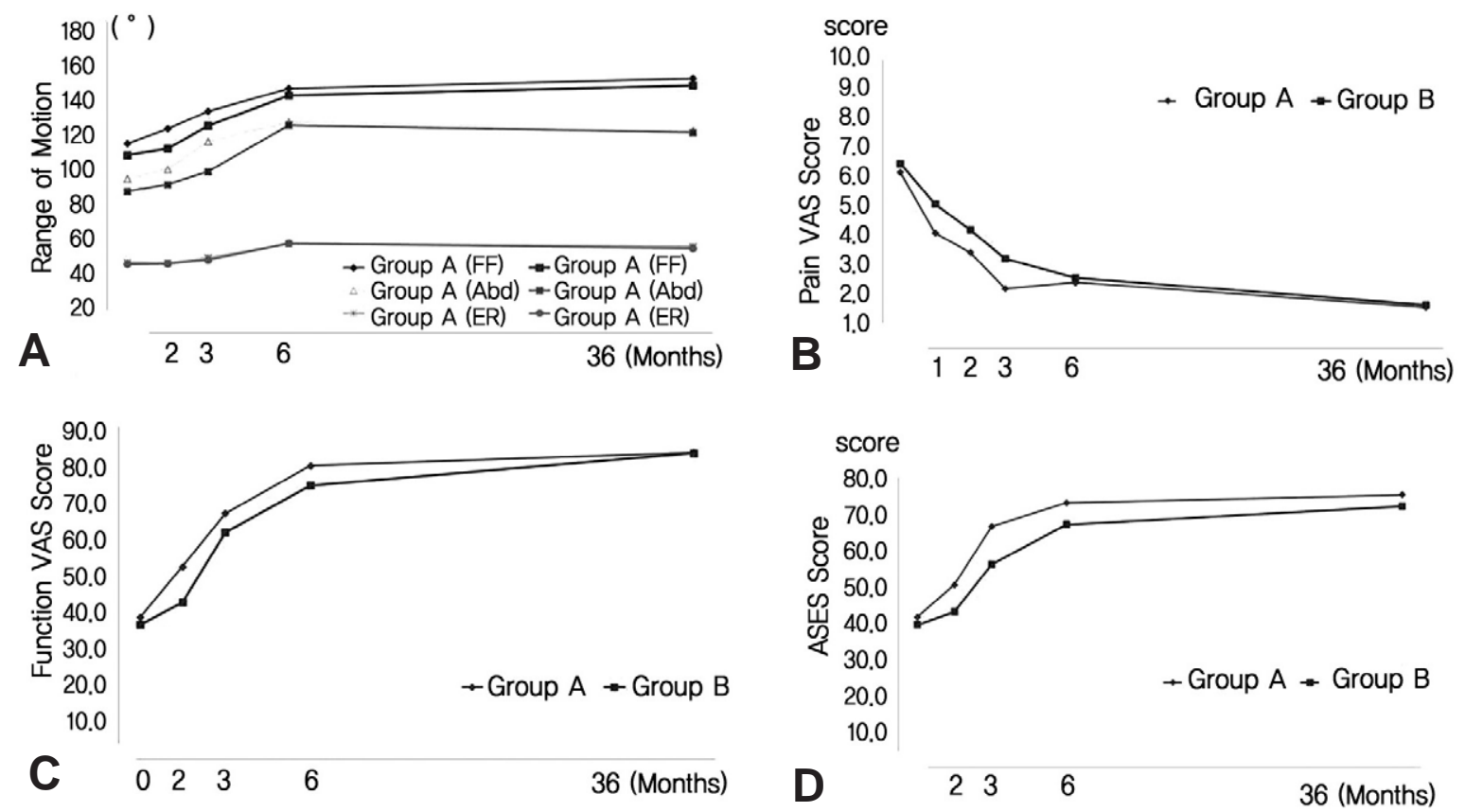

Fig. 1. The graphs show comparisons among arthroscopic, open rotator cuff repairs for (A) Range of motion, (B) Pain Visual Analogue Scale (VAS) score, (C) Function Visual Analogue Scale (VAS) score, (D) American Shoulder and Elbow Society (ASES) score. The data are displaced as mean \pm standard deviation of the mean.

Table 3. Comparison of range of motion preoperatively, postoperatively 3 months, 6 months and 3 years

\begin{tabular}{|c|c|c|c|}
\hline Range of motion & Group A & Group B & Group A versus Group B* \\
\hline \multicolumn{4}{|l|}{ Forward flexion } \\
\hline Preoperative & $113.4 \pm 3.6$ & $106.4 \pm 6.4$ & NS \\
\hline 3 months & $132.8 \pm 2.8$ & $124.1 \pm 4.3$ & $p^{*}<0.05$ \\
\hline 6 months & $146.3 \pm 4.1$ & $142.2 \pm 3.8$ & NS \\
\hline 3 years & $152.4 \pm 4.6$ & $148.2 \pm 5.2$ & NS \\
\hline \multicolumn{4}{|l|}{ Abduction } \\
\hline Preoperative & $92.3 \pm 6.4$ & $84.8 \pm 5.3$ & NS \\
\hline 3 months & $114.6 \pm 5.1$ & $96.7 \pm 4.2$ & $p^{*}<0.05$ \\
\hline 6 months & $126.3 \pm 5.6$ & $124.4 \pm 5.2$ & NS \\
\hline 3 years & $121.1 \pm 2.8$ & $120.1 \pm 5.2$ & NS \\
\hline \multicolumn{4}{|l|}{ External rotation } \\
\hline Preoperative & $42.3 \pm 3.2$ & $41.3 \pm 3.6$ & NS \\
\hline 3 months & $45.1 \pm 1.6$ & $43.8 \pm 2.6$ & NS \\
\hline 6 months & $53.4 \pm 2.4$ & $53.7 \pm 3.1$ & NS \\
\hline 3 years & $51.8 \pm 2.8$ & $50.8 \pm 2.0$ & NS \\
\hline
\end{tabular}

Group A: Arthroscopic repair, Group B: Open repair, Values are expressed as mean \pm standard deviation of the mean.

*: Mann-Whitney rank sum test, NS: No significant

견관절 기능 평가인 $\mathrm{KSS}$ 점수는 최종 추시에서 $\mathrm{A}$ 군은 평균 83.4 $\pm 5.8, \mathrm{~B}$ 군은 평균 $83.1 \pm 4.2$ 로 두 군 모두 만족할 만한 기능 향상을 보였으며 두 군간에 유의한 차이는 없었다.

합병증은 $\mathrm{A}$ 군에서 견관절 강직이 1 예 있었고 술 후 6 개월 추시상 골밀도가 -3.4 인 환자에서 봉합 나사못의 빠짐 (anchor pull out) 이 관찰되며 임상적으로 통증
이 지속되어 재수술을 1 예 시행하였다. B군에서는 초기 강직이 3 예 있었으며 삼각근의 손상으로 통증이 장기간 지속되었으나 최종 추시에서 삼각근의 위축은 없었다.

\section{고 찰}

회전근 개의 대 파열이나 광범위 파열은 결손의 광범 
Table 3. Comparison of range of motion preoperatively, postoperatively 3 months, 6 months and 3 years

\begin{tabular}{|c|c|c|c|}
\hline Range of motion & Group A & Group B & Group A versus Group B* \\
\hline \multicolumn{4}{|l|}{ Pain VAS } \\
\hline Preoperative & $6.1 \pm 1.6$ & $6.4 \pm 1.2$ & NS \\
\hline 3 months & $2.1 \pm 0.9$ & $3.1 \pm 1.0$ & $p^{*}<0.01$ \\
\hline 6 months & $2.3 \pm 0.9$ & $2.5 \pm 1.1$ & NS \\
\hline 3 years & $1.4 \pm 0.8$ & $1.5 \pm 1.0$ & NS \\
\hline \multicolumn{4}{|l|}{ Function VAS } \\
\hline Preoperative & $41.5 \pm 9.9$ & $39.4 \pm 9.3$ & NS \\
\hline 3 months & $66.5 \pm 6.5$ & $56.1 \pm 5.2$ & $p^{*}<0.01$ \\
\hline 6 months & $73.0 \pm 4.7$ & $67.1 \pm 3.8$ & $p^{*}<0.05$ \\
\hline 3 years & $75.2 \pm 3.8$ & $72.1 \pm 2.9$ & NS \\
\hline \multicolumn{4}{|l|}{ ASES score } \\
\hline Preoperative & $38.3 \pm 9.6$ & $36.3 \pm 7.1$ & NS \\
\hline 3 months & $66.5 \pm 6.5$ & $61.3 \pm 7.1$ & $p^{*}<0.01$ \\
\hline 6 months & $79.5 \pm 5.8$ & $74.1 \pm 5.1$ & $p^{*}<0.05$ \\
\hline 3 years & $83.1 \pm 6.1$ & $82.9 \pm 3.6$ & NS \\
\hline
\end{tabular}

Group A: Arthroscopic repair, Group B: Open repair, Values are expressed as mean \pm standard deviation of the mean.

*: Mann-Whitney rank sum test, NS: No significant.

위한 크기, 넓고 심한 유착, 파열건의 과다한 전위 및 건 자체의 퇴행성 변화로 인해 수술적 봉합에 어려움이 있으나. ${ }^{16,17)}$ 통증의 완화 및 기능의 호전면에서 수술 후 70 95\%의 만족스러운 결과들이 보고됨에 따라 ${ }^{11.16 .17)}$ 수술적 봉합술이 널리 사용되고 있다. 한편, Levy 등 ${ }^{18}$ 은 초기 관절경적 봉합술에서 소, 중 파열군의 결과와 대, 광범위 파열의 결과에 차이가 있었다고 하였으며 Paulos와 $\mathrm{Kody}^{4}$ 는 만성의 대 파열이 있을 경우 고식 적인 접근을 하는 것이 좋다고 제안했다. 그러나, 개방 적 봉합술은 술 후 통증의 지속 기간이 길고 견봉내 삼 각근의 재부착 후 삼각근의 파열이나 약화가 발생할 가 능성이 있어 조기 재활에 제한이 있다. ${ }^{19.20)}$ 이에 병변에 대한 소 절개를 통한 봉합술을 시행하기도 하는데 ${ }^{21.22)}$ 제한된 노출, 병변부로의 접근의 어려움 및 삼각근 기 시부를 박리하지 않음에도 불구하고 여전히 삼각근의 손상이 발생할 가능성이 있다. 최근 관절경적 회전근 개 봉합술로 치료한 광범위 파열 환자의 장기간 임상 추시 결과 통증, 기능, 근력 및 운동 범위에서 술 전과 비교하여 의미 있게 호전되어 만족할 만한 결과들이 보 고되고 있으멸.23) Jones 와 Savoie ${ }^{9)}$ 는 광범위 회전근 개 파열 환자를 대상으로 관절경적 봉합술을 시행한 결 과 $88 \%$ 에서 만족스러운 결과를 얻었다고 보고하였다. 이에 저자들은 회전근 개의 대 파열이나 광범위 파열에 서 개방적 봉합술이 주로 시행되고 있으나 관절경을 이 용한 봉합술이 개방적 술기의 제한점을 보완할 수 있을 것으로 생각하였고 대 파열 및 광범위 회전근 개 파열 에서 관절경적 봉합술과 개방적 봉합술의 중기 임상 결 과를 비교 분석하였다.

임상적 결과는 관절운동 범위, 통증 정도 및 견관절
기능 평가에서 두 군 모두 수술 전에 비해 만족할 만한 향상을 보였으며 최종 추시에서 두 군간에 통계학적으 로 유의한 차이는 없었다. 그러나, 관절경적 봉합술에 서 보다 우수한 초기 임상적 결과를 보였는데, 이는 관 절경적 봉합술이 개방적 봉합술에 비해 덜 침습적인 술 기로써 술 후 통증의 지속 기간이 짧고 개방적 봉합술 에 비해 조기에 수동 운동을 시작할 수 있어 초기 유착 및 강직이 1 예로 적었으며, 이에 관절경적 봉합술을 시 행받은 환자에서 객관적 및 주관적 만족도가 더 높았던 것으로 생각되었다. 그러나 개방적 봉합술 20예 중에는 관절경하 봉합 나사를 삽입하였으나 골의 상태가 불량 하여 수술 시야상 봉합 나사못의 빠짐이 관찰되어 개방 적 봉합술로 전환한 경우가 2예 있었으며 장시간의 수 술 시간에 따른 견관절 주위로의 심한 부종과 회전근 개의 넓고 심한 유착, 파열건의 과다한 전위로 관절경 적 봉합이 어려워 개방적 봉합술로 전환한 경우가 1 예 있었다. 이로 미루어볼 때 소 파열이나 중 파열 뿐만 아니라 대 파열 및 광범위 파열에서도 관절경적 봉합술 이 만족할 만한 수술적 봉합법이긴 하나 술 전 회전근 개의 상태나 환자 상태가 정확히 평가되어야 하며 관절 경적 봉합술시에도 개방적 봉합술로의 전환 가능성을 언제나 염두해 두어야 할 것으로 생각되었다.

한편, 광범위 파열에서 극상건이나 극하건의 심한 지 방변성, 견갑하근의 동반된 파열 및 진행된 근 위축의 경우는 해부학적 완전 봉합이 불가능할 수 있으면) 이 를 극복하기 위한 방법으로써 변연절제술, 건 이전술, 부분 봉합술 및 역행성 견관절 전 치환술 등이 시도되 고 있다. ${ }^{25-28)}$ 이중, 부분 봉합술은 해부학적 완전 봉합 이 불가능한 경우의 대안으로써 보다 침습적이고 합병 
증의 가능성이 큰 수술을 시행하기에 환자의 건강상태 등이 좋지 않은 경우나 역행성 견관절 전 치환술을 시 행하기에 상대적으로 젊은 연령에 있어서 큰 위험부담 없이 시행할 수 있으면서도 상대적으로 좋은 기능적 결 과를 보이는 수술 방법으로서 ${ }^{29.30)}$ 저자들의 경우, 광범 위 파열에서 해부학적 완전 봉합이 불가능한 경우가 두 군 모두에서 각각 3 예씩 있었으며 이에 대해 부분 봉합 술을 시행하였고 일부 결손 부위에 추가적으로 상완 이 두 장두건을 이용한 건성형술을 시행하였다. 최종 추시 상 임상적 결과는 수술 전에 비해 두 군 모두 만족할 만한 향상을 보였으며 광범위 파열에서 해부학적 완전 봉합이 어려운 경우 시행할 수 있는 좋은 수술적 치료 중의 하나라고 생각되었다.

Park 등 ${ }^{31}$ 은 회전근 개 파열 크기가 중 파열 이하일 때는 수술 방법에 따른 견관절 기능에 차이가 없으나 대 파열과 광범위 파열일 경우 이열 봉합술이 의미 있 게 향상된 견관절 기능점수를 나타내어 이열 봉합술의 우위를 보고하였는데, 저자들의 경우도 관절경적 봉합 술시 이열 봉합술이 가능한 조직 상태에서는 이열 봉합 술을 시행함으로써 대 파열과 광범위 파열에서 더 나은 기능 점수를 얻고자 하였다.

본 연구는 후향적이며 두 환자군 간의 유사성이 있으 나 비무작위로 이루어졌고 관절경적 술기의 숙달기간 동안 수술 방법의 선택에 술자의 편견이 있으며 두 군 간의 술 후 재활에 차이가 있다는 제한이 있다. 또한 대 파열이나 광범위 파열은 소 파열이나 중 파열에 비 해 재파열이 흔하며 ${ }^{3)}$ 수술 방법에 관계없이 $20 ~ 60 \%$ 의 재파열이 보고되고 있다. ${ }^{32-34)}$ 그러나, 본 연구에서는 술 후 두 군간의 회전근 개의 재파열 여부와 정도를 객관 적으로 알아보기 위한 초음파나 자기공명영상 촬영을 시행하지 않아, 향후 회전근 개의 관절경적 봉합술과 개방적 봉합술 후 초음파나 자기공명영상을 이용한 비 교연구가 필요할 것으로 생각한다.

\section{결 론}

회전근 개 대 파열 및 광범위 파열에서 관절경적 봉 합술이 개방적 봉합술보다 우수한 초기 임상 결과를 보 였으나, 최소36개월 이상의 추시에서 관절경적 봉합술 과 개방적 봉합술 모두 향상된 중기 임상 결과를 얻을 수 있었다.

\section{참 고 문 헌}

1) McKee MD, Yoo DJ. The effect of surgery for rotator cuff disease on general health status. Results of a prospective trial. J Bone Joint Surg Am. 2000;82:970-9.
2) Zumstein MA, Jost B, Hempel J, Hodler J, Gerber C. The clinical and structural long-term results of open repair of massive tears of the rotator cuff. $J$ Bone Joint Surg Am. 2008;90:2423-31.

3) Klepps S, Bishop J, Lin J, et al. Prospective evaluation of the effect of rotator cuff integrity on the outcome of open rotator cuff repairs. Am J Sports Med. 2004; 32:1716-22.

4) Paulos LE, Kody MH. Arthroscopically Enhanced "Miniapproach"to Ro"tator Cuff Repair. Am J Sports Med. 1994;22:19-25.

5) Murray TF Jr, Lajtai G, Mileski RM, Snyder SJ. Arthroscopic repair of medium to large full-thickness rotator cuff tears: outcome at 2- to 6-year follow-up. $J$ Shoulder Elbow Surg. 2002;11:19-24.

6) Severud EL, Ruotolo C, Abbott DD, Nottage WM. All-arthroscopic versus mini-open rotator cuff repair: A long-term retrospective outcome comparison. Arthroscopy. 2003;19:234-8.

7) Wilson F, Hinov V, Adams G. Arthroscopic repair of full-thickness tears of the rotator cuff: 2- to 14-year follow-up. Arthroscopy. 2002;18:136-44.

8) Burkhart SS, Danaceau SM, Pearce CE. Arthroscopic rotator cuff repair: analysis of results by tear size and by repair technique: Margin convergence versus direct tendon-to-bone. Arthroscopy. 2001;17:905-12.

9) Jones CK, Savoie FH. Arthroscopic repair of large and massive rotator cuff tears. Arthroscopy. 2003;19: 564-71.

10) Cofield RH. Current concept review. Rotator cuff disease of the shoulder. J Bone Joint Surg Am. 1985;67: 974-9.

11) Cerber C, Fuchs B, Hodler J. The results of repair of massive tears of the rotator cuff. J Bone Joint Surg Am. 2000;82:505-15.

12) Wierks C, Skolasky RL, Ji JH, McFarland EG. Reverse total shoulder replacement: intraoperative and early postoperative complications. Clin Orthop Relat Res. 2009;467:225-34.

13) Yoo JC, Kim JH, Lee YS, Park JH, Kang HJ. Arthroscopic double mattress repair in incomplete subscapularis tears. Orthopedics. 2008;31:851-4.

14) Richards RR, An KN, Blgliani LU, et al. A standardized method for the assessment of shoulder function. $J$ shoulder Elbow Surg. 1994;3:347-52.

15) Tae SK, Rhee YG, Park TS, et al. The development and validation of an appraisal method for rotator cuff disorders. The Korean Shoulder Scoring System. J Shoulder Elbow Surg. 2009;18:689-96.

16) Bigliani LU, Cordasco FA, McIlveen SJ, Musso ES. Operative repair of massive rotator cuff tears. Longterm results. J Shoulder Elbow Surg. 1992;1:120-30.

17) Nobuhara K, Hata Y, Komai M. Surgical procedures and results of repair of massive tears of the rotator cuff. Clin Orthop Relat Res. 1994;304:54-9. 
18) Levy HJ, Uribe JW, Kelaney LG. Arthroscopic assisted rotator cuff repair: preliminary results. Arthroscopy. 1990;6:55-60.

19) Karas EH, Iannotti JP. Failed repair of the rotator cuff: evaluation and treatment of complication. Instr Course Lect. 1998;47:87-95.

20) Seo JB, Bahng SC. Early complications after repair of massive rotator cuff tear. J Korean Shoulder Elbow Soc. 2006;9:27-33.

21) Romeo AA, Hang DW, Bach BR, Shott S. Repair of full thickness rotator cuff tears. Clin Orthop Relat Res. 1999;367:243-55.

22) Kim SH, Ha KI, Park JH, Kang JS, Oh SK, Oh IV. Arthroscopic versus mini-open salvage repair of the rotator cuff tear: Outcome analysis at 2 to 6 years' follow-up. Arthroscopy. 2003;19:746-54.

23) Sugaya H, Maeda K, Matsuki K, Moriishi J. Functional and structural outcome after arthroscopic full thickness rotator cuff repair: single-row versus dualrow fixation. Arthroscopy. 2005;21:1307-16.

24) Yoo JC, Ahn JH, Yang JH, Koh KH, Choi SH, Yoon YC. Correlation of arthroscopic repairability of large to massive rotator cuff tears with preoperative magnetic resonance imaging scans. Arthroscopy. 2009;25:573-82.

25) Rockwood CA, Williams GR, Burkhead WZ. Debridement of degenerative, irreparable lesions of the rotator cuff. J Bone Joint Surg Am. 1995;77:857-66.

26) Elhassan B, Ozbaydar M, Massimini D, Diller D, Higgins L, Warner JJ. Transfer of pectoralis major for the treatment of irreparable tears of subscapularis: does it work? J Bone Joint Surg Br. 2008;90:1059-65.

27) Moser M, Jablonski MV, Horodyski M, Wright TW. Functional outcome of surgically treated massive rotator cuff tears: a comparison of complete repair, partial repair, and debridement. Orthopedics. 2007;30:479-82.

28) Gerber C, Pennington SD, Nyffeler RW. Reverse total shoulder arthroplasty. J Am Acad Orthop Surg. 2009; 17:284-95.

29) Duralde XA, Bair B. Massive rotator cuff tears: the result of partial rotator cuff repair. J Shoulder Elbow Surg. 2005;14:121-7.

30) Yoo JC, Ko KH, Woo KJ. Clinical result of arthroscopic partial repairs in massive rotator cuff tears. $J$ Korean Shoulder Elbow Soc. 2009;12:150-8.

31) Park JY, Lhee SH, Choi JH, Park HK, Yu JW, Seo JB. Comparison of the clinical outcomes of single with double row repair in rotator cuff tears. Am J Sports Med. 2008;36:1310-6.

32) Calvert PT, Packer NP, Stoker DJ, Bayley JI, Kessel L. Arthrography of the shoulder after operative repair of the torn rotator cuff. J Bone Joint Surg Br. 1986;68: 147-50.

33) Hanusch BC, Goodchild L, Finn P, Rangan A. Large and massive tears of the rotator cuff: functional outcome and integrity of the repair after a mini-open procedure. J Bone Joint Surg Br. 2009;91:201-5.

34) Liu SH, Baker CL. Arthroscopically assisted rotator cuff repair: correlation of functional results with integrity of the cuff. Arthroscopy. 1994;10:54-60.

\section{초 록}

서론: 회전근 개 대 파열 및 광범위 파열에 대한 관절경적 봉합술 군과 개방적 봉합술 군 간의 중 기 임상적 결과를 비교 분석하였다.

대상 및 방법: 회전근 개 대 파열 및 광범위 파열에 대해 봉합술을 실시한 48 예 를 후향적으로 분석하였다. 관절경적 봉합술을 시행한 군은 28 예, 개방적 봉합술을 시행한 군은 20 예 였다. 임 상적 결과는 관절운동 범위, 통증과 기능에 대한 $\mathrm{VAS}, \mathrm{ASES}$ 점수 및 $\mathrm{KSS}$ 점수를 평가하였다. 결과: 관절운동 범위, 통증에 대한 $\mathrm{VAS}$ 점수, 기능에 대한 $\mathrm{VAS}$ 점수 및 $\mathrm{ASES}$ 점수는 두 군 모두 술 전에 비해 최종 추시상 의미있는 향상을 보였으나 최종 추시상 두 군간에 통계학적으로 유의한 차이는 없었다 $(p>0.05) . \mathrm{KSS}$ 점수도 최종 추시상 두 군간에 통계학적으로 유의한 차이 는 없었다 $(p>0.05)$.

결론: 관절경적 봉합술과 개방적 봉합술 모두 향상된 중기 임상 결과를 얻을 수 있었으며 두 군간 에 의미있는 차이는 없었다.

색인 단어: 회전근 개, 대 파열, 광범위 파열, 관절경적 봉합술, 개방적 봉합술 